\title{
Belgeo
}

Revue belge de géographie

$4 \mid 2001$

Miscellaneous

\section{The international migratory model of Spain. Changes and new challenges for the XXI ${ }^{\text {st }}$ century}

Le modèle migratoire espagnol. Changements et nouveaux défis à l'aube du XXI siècle

José $\mathrm{M}^{\mathrm{a}}$. Serrano Martínez

\section{OpenEdition}

\section{Journals}

Electronic version

URL: https://journals.openedition.org/belgeo/15770

DOI: 10.4000/belgeo.15770

ISSN: 2294-9135

Publisher:

National Committee of Geography of Belgium, Société Royale Belge de Géographie

Printed version

Date of publication: 30 December 2001

Number of pages: $377-398$

ISSN: 1377-2368

\section{Electronic reference}

José $M^{a}$. Serrano Martínez, "The international migratory model of Spain. Changes and new challenges for the XXIst century", Belgeo [Online], 4 | 2001, Online since 31 December 2001, connection on 15

November 2021. URL: http://journals.openedition.org/belgeo/15770 ; DOI: https://doi.org/10.4000/ belgeo.15770

This text was automatically generated on 15 November 2021.

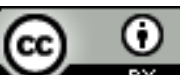

Belgeo est mis à disposition selon les termes de la licence Creative Commons Attribution 4.0 International. 


\title{
The international migratory model of Spain. Changes and new challenges for the $\mathrm{XXI}^{\text {st }}$ century
}

\author{
Le modèle migratoire espagnol. Changements et nouveaux défis à l'aube du XXIe \\ siècle
}

José $M^{a}$. Serrano Martínez

1 To a certain degree the history of humanity is the continuous movement of human groups from one part of the planet to another. In those movements, people, as Michel de Montaigne said centuries ago, always search for their wellbeing and freedom. Both are supreme conditions yearned for by all human beings. What happens is that our perception of both concepts varies through time and acquires nuances and disparate features. But fundamentally their essence remains.

2 Migratory flows do not usually remain steady for long; on the contrary, there are times and moments when they increase, and there are others when they diminish and reduce. Everything depends on numerous circumstances. At present, migratory flows within the European environment are occurring on a significant scale. Their volume increases year after year and seems to exceed the levels that have been calculated as maximum hypotheses. What happens is that each country registers different features in its various regions, which gives greater complexity to the phenomenon.

In essence, this is due to a combination of several factors: primary amongst these is the significant and growing difference in income level, economic development and quality of life between most of the countries of Western Europe and the neighbouring areas or those farther away. In the same way the ease of movement of people from one place to another is increasing.

4 This migratory phenomenon, growing larger over the years, raises numerous questions that are difficult to solve but which it is necessary to face with realism, perspicacity and long-term vision. I believe that it is out of place to pose maximalist positions, since they 
hardly function, are ineffective and, even, unjust. Neither should there be allowance for suicidal demagoguery that solves nothing.

5 To try to approach the question of international migration with the seriousness and attention it deserves, the first thing of interest is to know its size and structure with the greatest possible precision. This is not simple, because the very statistics we are obliged to use come from official sources, but it is known that a wider reality exists that remains outside normal control. The capacity of human beings to take advantage of the opportunities presented to them is great, especially when it concerns their own wellbeing.

\section{The traditional migration model of Spain}

It is not appropriate to present a detailed analysis of this matter here for it is not our central theme. However, it is useful briefly to devote some attention to it, in order to establish the background to the current situation.

7 It can be stated emphatically that, during the twentieth century, an appreciable volume of people has left Spain for other countries. Although they were not as numerous, in absolute terms, as those from other Mediterranean countries or from other parts of Europe, it can be stated that Spain has been one of the European countries that has participated significantly in emigration flows. A brief summary of what occurred is shown in Table 1.

Table 1. Significance of Spanish emigration in the twentieth century.

\begin{tabular}{ccccc} 
Period & $\begin{array}{c}\text { Total } \\
\text { emigration }\end{array}$ & $\begin{array}{c}\% \\
\text { America }\end{array}$ & $\begin{array}{c}\% \\
\text { Europe }\end{array}$ & $\begin{array}{c}\text { \% Rest of } \\
\text { the world }\end{array}$ \\
\hline $1901-05$ & 396,183 & 69.87 & 1.83 & 28.30 \\
$1906-10$ & 348,910 & 67.90 & 2.46 & 29.64 \\
$1911-15$ & 713,055 & 82.31 & 1.67 & 16.02 \\
$1916-20$ & 818,486 & 79.37 & 4.08 & 16.55 \\
$1921-25$ & 453,878 & 88.36 & 2.53 & 9.11 \\
$1926-30$ & 484,115 & 86.03 & 1.68 & 12.29 \\
$1931-35$ & 376,340 & 80.43 & 2.21 & 17.36 \\
$1936-40$ & 212,598 & 51.06 & 5.29 & 43.65 \\
$1941-45$ & 33,099 & 55.94 & 15.74 & 28.32 \\
$1946-50$ & 66,242 & 24.21 & 0.99 & 74.80 \\
$1951-55$ & 191,075 & 70.90 & 3.90 & 25.20 \\
$1956-60$ & 379,089 & 71.95 & 1.81 & 26.24 \\
$1961-65$ & 269,950 & 83.84 & 11.60 & 5.00 \\
$1966-70$ & 410,789 & 24.18 & 74.11 & 1.71 \\
$1971-75$ & 412,945 & 11.86 & 86.80 & 1.34 \\
$1976-80$ & 80,111 & 14.18 & 77.88 & 7.94 \\
$1981-85$ & 116,206 & 5.63 & 73.43 & 20.94 \\
$1986-90$ & 79,738 & 4.92 & 90.25 & 9.75 \\
$1991-95$ & 22,429 & 15.53 & 79.62 & 4.85 \\
& & & & \\
\hline
\end{tabular}

SOURCE: BASED ON DATA OF THE INE AND DIRECCIÓN GENERAL DE MIgRACIONES 
If we add all the people counted as emigrants during the century, we would have an inflated figure of several millions, but it should be noted that a substantial proportion of them emigrated but then returned to Spain after a variable period of temporary emigration (Vilar J.B., Vilar Ma. J., 1999a). In some cases this period was a few years, while in others it lasted throughout the emigrants' working lifetime.

Consideration of Table 1 indicates a succession of temporary cycles involving periods of very strong emigration flows, followed by years with fewer movers. During the whole first third of the century the figures were high, attaining their greatest volumes in the 5-year periods between 1910 and 1920. During the Spanish civil war and in the following years many of those who emigrated from Spain were not counted. Their number decreased in an appreciable way in the years of the Spanish post-war period, which coincided in its first years with the outbreak of the Second World War. Then, starting from the 1950s a recovery in the figures occurs, reaching a maximum again during the years 60-75. From then on, one enters into a period of marked reduction in the emigration departures.

The existence of these cycles and the main elements that caused them are evidently not something fortuitous. On the contrary, they result from a combination of internal and external causes. A few comments should be made here:

- As can be seen in the third column of Table 1, a high percentage of the early twentieth century emigrants, between $67.9 \%$ and $88.36 \%$, went to the Americas. Within the American continents, the Ibero-American countries, from Mexico to Argentina, were the main receiver countries for Spaniards because in those years several of those countries had policies of open immigration aiming to attain rapid economic development, the colonisation of new lands, and the creation of other industrial activities and services. Thus Argentina, Brazil and Mexico were the top priority destinations. The ease of the language was always, in such movements, an added circumstance that favoured the arrival of Spaniards. In this respect one can refer to the excellent work by J. García Fernández (1965).

- This period of mass departures from Spain which, with slight variations, existed throughout the whole first third of the century, corresponded to a time of strong demographic growth in Spain which was not accompanied by an adequate process of economic growth through industrialisation, which would have given employment to the manpower surplus generated by the mostly rural world of the time (Vilar J.B., Vilar Ma. J., 1999b). An appreciable part of these people saw emigration as the opportunity to improve their fortune (Palazón Ferrando, 1999).

- It is easy to understand the strong reduction of the flow of Spanish emigrants between 1936 and 1950. After the frustrated expectations created by the 2nd Republic (1931-36), the consequent civil conflict (1936-39) resulted for some years in a total rupture of Spanish domestic normality. The repression that followed motivated sizeable emigrant departures of the defeated and of those whose ideology didn't fit the Spain of the winners. But the closing of frontiers imposed in the early years of Franco's dictatorship prevented the departures from being larger.

- After the first years of the post-war period, a new emigration cycle started, of a different nature. During the 1950s Spanish population growth continued, with a high birth rate and consequent natural increase. Inside Spain, important socio-economic transformations began to take place. The beginnings of industrialisation and the mechanisation of agriculture precipitated a tremendous rural exodus, which developed parallel to the increment of the emigration flows. 
- But in the new cycle from 1951 to 1975 , with the maximum attained in 1966-75, there was the succession of two priority destinations for Spanish emigrants. Until 1965, the western hemisphere countries continued to be the main receivers, and more specifically the IberoAmerican countries, ahead of the United States and Canada which, together with other English-speaking countries, received a minimum proportion of the Spaniards arriving in the Americas.

- After the mid-1960s, the destination of the majority of Spanish emigrants changed to the neighbouring countries of Western Europe. These received the largest proportions of emigrants so that, between 1966 and 1975, these destinations accounted for 74 to $86 \%$ of the total. The main causes of these movements were, besides proximity and ease of movement, the appreciable salary differences between these European countries and Spain. France, Germany, Holland, Belgium and Switzerland become the places chosen by most of the emigrants from Spain (Hermet, 1969; Parra, 1981; Vilar, 2000). The strong economic growth of those countries at that time required an abundant unskilled workforce which the Spaniards, as well as other citizens from Southern Europe, could provide.

- But Spanish emigration today constitutes a closed cycle, of which there are now only the remains (Serrano Martínez, 1998a). Only a few thousand emigrants with their families continue living in Switzerland, Germany and other countries and every year there are more returns than departures, which during recent years have been very modest in numbers (Sempere Souvannavong, 2000).

11 Likewise, it is interesting to highlight, from 1975, when Franco's dictatorship ended and the new regime began, a period of strong social and economic transformation coinciding with a marked decrease in emigration. There was an economic crisis from 1978 to 1985 accompanied by industrial restructuring; unemployment rates grew significantly. However, external flows decreased progressively. It could be said that there was a kind of «exaggerated affection» by Spaniards for their country. Even though it is not easy to understand such a situation objectively, the situation presented by the statistics is indicative (Serrano Martínez, 1997).

It should be stressed that, although at present there are no important emigration flows, it is often forgotten that as a consequence of the strong emigration flows of past decades, there is still a large presence of Spanish residents abroad, as shown in Table 2.

Table 2. Spanish residents abroad, data for 1998.

\begin{tabular}{lcc} 
Continent & Absolute figures & $\%$ of the total \\
\hline Europe & 749,024 & 37.54 \\
bero-America & $1,092,974$ & 54.78 \\
Remainder of Americas & 115,864 & 5.80 \\
Africa & 14,142 & 0.70 \\
Asia & 9,332 & 0.46 \\
Oceania & 13,856 & 0.69 \\
\hline & & \\
Total & $1,995,192$ & 100.00
\end{tabular}

SOURCE: BASED ON DATA OF THE INE AND DIRECCIÓN GENERAL DE MIgRACIONES 
Inspection of Table 2 suggests the following more notable features:

- Almost two million Spaniards live outside Spain's borders. This is a significant figure in comparison with the total Spanish population: almost $5 \%$ of the total. As we will see later on, this still constitutes a larger figure than that of foreign residents in Spain.

- The spatial distribution of Spaniards abroad shows a close relationship with the main tendencies of the external migratory flows. So $54.78 \%$ of them are in Ibero-America, followed a long way behind by Europe, with $37.54 \%$. As explained earlier, both destinations have been, with some differences, those that welcomed the largest number of Spanish emigrants during the entire century.

- These communities are a direct inheritance from past emigration flows. Meanwhile many of the emigrants, either pensioners or close to pensionable age, remain living in their places of settlement. In many cases, family ties justify their permanency in those places but the attachment to their original land explains the maintenance of their nationality. However, their number is progressively diminishing.

\section{The beginning of the arrival of immigrants in Spain}

14 In Spain, in contrast to what happened in other neighbouring countries, there were no occurrences of significant immigration flows during modern times. While during the XIX $^{\text {th }}$ century the industrial revolution swept over a good part of Western Europe, Spain was involved to a much lesser extent than elswehere. The country's economic backwardness and its growing economic distance from the more developed countries held back the growth of both employment and wealth, that might have attracted large groups of people from other nations. It must thus be emphasised that Spain lacked a history and experience of immigration, both on the part of the ordinary population and on the part of the authorities at various levels. Immigration therefore constitutes a new phenomenon. The numerous questions it poses relate to situations that have never been experienced before (Izquierdo, 1995). It has been useful, consequently, to see what has been done, and how this issue has evolved in neighbouring countries with more experience.

If the appearance of immigration is recent, its evolution has been rapid. Nothing proves this better than the data in Table 3 .

Table 3. Migratory balances. Increase in the foreign residents in Spain.

\begin{tabular}{ccc} 
& Absolute data & $1975=100$ \\
\hline 1975 & 165,289 & 100 \\
1980 & 182,045 & 110.13 \\
1985 & 211,971 & 128.24 \\
1990 & 407,657 & 246.63 \\
1995 & 499,773 & 302.36 \\
1996 & 538,984 & 326.08 \\
1997 & 609,813 & 368.93 \\
1998 & 719,647 & 435.38 \\
1999 & 801,329 & 484.80
\end{tabular}

SOURCE: BASED ON DATA OF THE INE AND DIRECCIÓN GENERAL DE MIgRACIONES 
First, one must remember that the table only includes official data on legal foreign residents in Spain; it excludes all those who, in one way or another, entered the country illegally. This is an important issue because it is estimated that there is a great number of such «illegals» present in Spain. This can be better understood through consideration of the following more important issues:

- Spain's terrestrial and marine frontiers are extensive and permeable. Moreover the country's location, in the southern area of the Mediterranean, only a few kilometres from Africa, as well as the location of the Canaries close to the African coast, make it easy for people to enter Spain illegally. For some years this has become a daily phenomenon.

- Spain has for some years been one of the main tourist destinations in the world. More than 40 million foreigners arrive in the country every year, making it one of the most open countries. It is necessary to have numerous broad access channels, through which the tourists can have access to the country with relative ease, but because of these tourist flows it is easy for those who want to enter illegally to find some camouflage.

- Once inside, due to the lack of Spain's experience in these matters it has not been, up to now, difficult to escape the weak existing controls. At the same time, the non-existence of a coherent and stable migratory policy has favoured the growth of the number of foreign residents living on the margins of official controls.

All this explains why it has been necessary to proceed, several times, to the legalisation of illegal residents, with the purpose of adapting legality to reality. But such a process impels many people to follow an illegal path.

In spite of all this, it is necessary to work on the basis of the official data, even knowing that the reality involves volumes that considerably exceed these figures. The number of illegal residents, by their very nature, cannot be measured accurately: they can only be estimated.

As indicated earlier, the number of legal foreign residents in Spain has been growing in recent years. Up to 1985 growth was slow (Gozálvez Pérez, 1996). In ten years (1975-85) an increase was recorded of less than fifty thousand persons. But after that growth intensified. Between 1985 and 1990, more than 195,000 new residents were added and, in the first half of the next decade, 1990-95, another 92,000. Since then, every year tens of thousands more new people have been added and this trend is continuing.

In absolute terms, the number of legal residents has increased by 636,040 persons between 1975 and 1999. Perhaps the most significant thing is not the total figure reached at present, but the speed and the relentless rhythm it shows in its evolution. The percentage of the population of Spain that they represent has increased from $0.4 \%$ to approximately $2 \%$. Taking the number of foreign residents in 1975 as represented by 100 , that value has since increased to 484 , or in other words, multiplied by almost five. 
Figure 1. Foreign residents in Spain: absolute values.

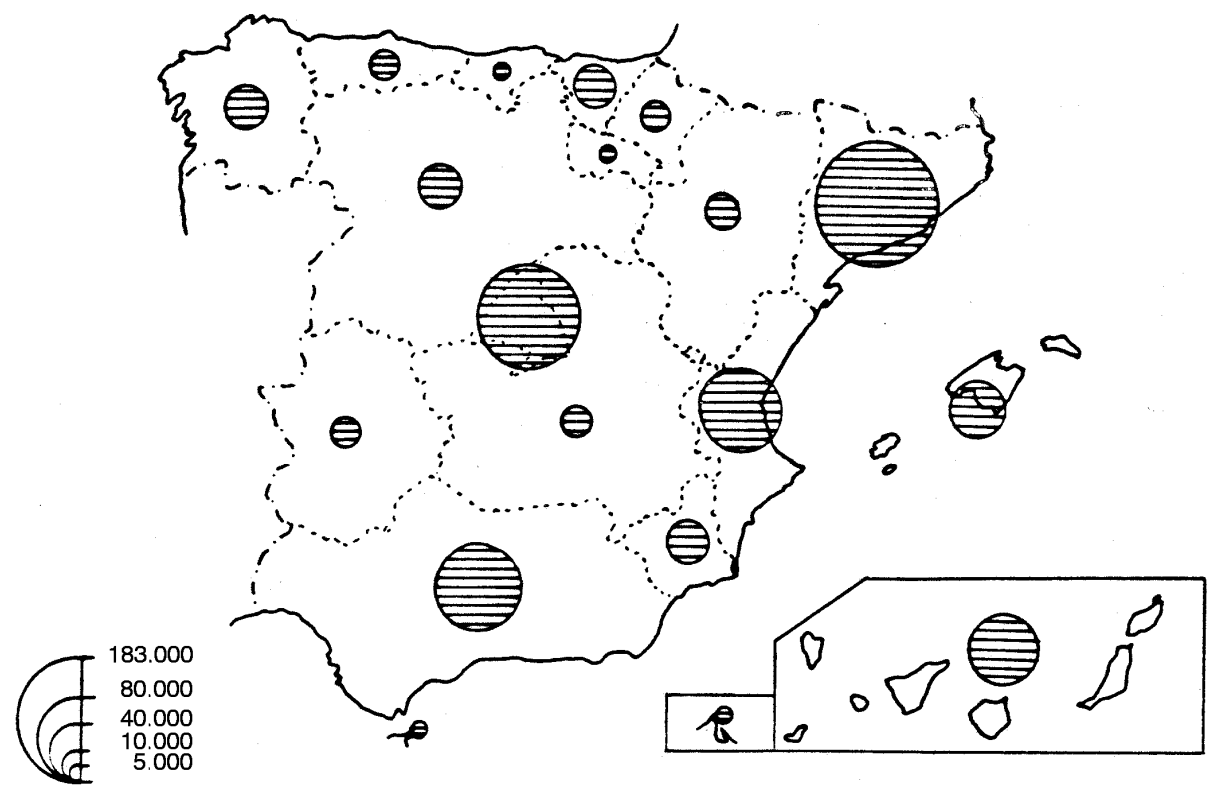

$0 \quad 100 \quad 200 \quad 300 \mathrm{~km}$

Figure 2. Foreign residents in Spain: value \% of the total population.

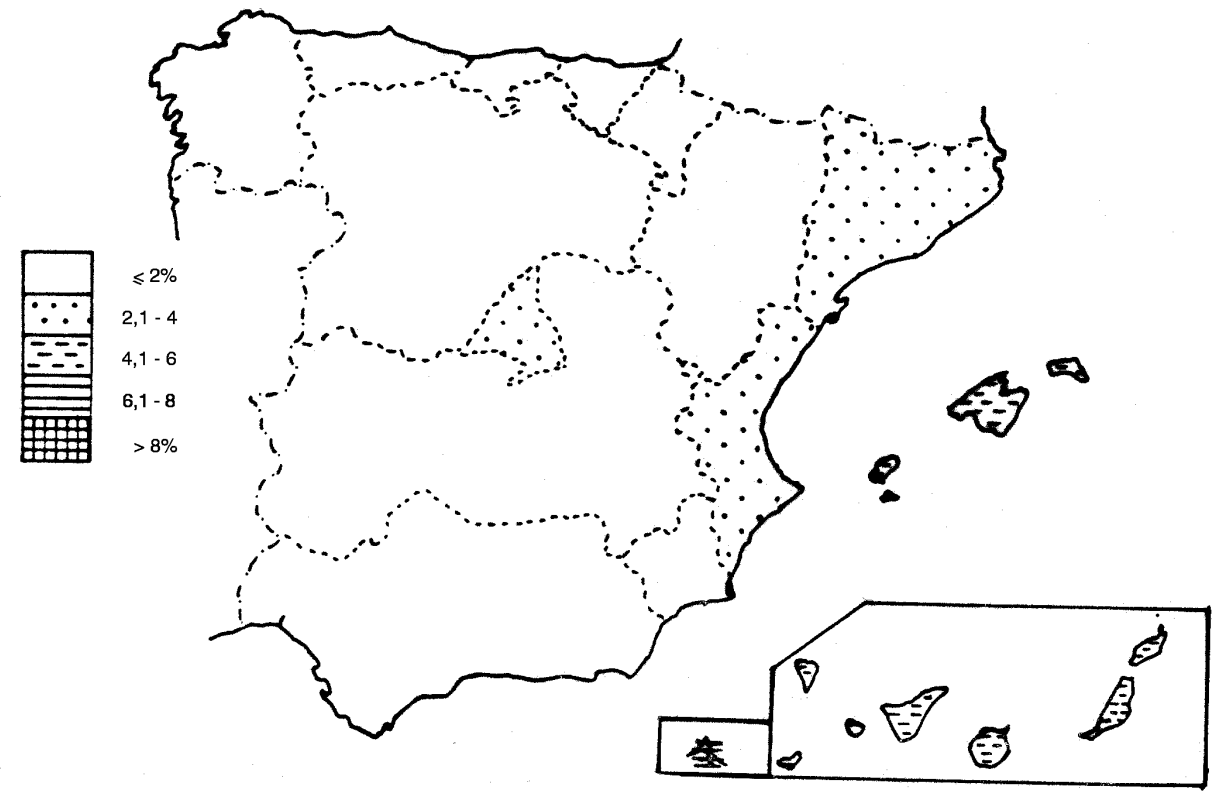

21 Foreign residents in Spain have arrived for very different reasons. One cannot speak of immigration homogeneity (López de Lera, 1995). On the contrary, the heterogeneity of the causes that have impelled them to come, their origins and objectives is obvious (López Trigal, 2000).

It must be emphasised that for the majority of the immigrants their arrival has been determined by economic factors (Gozálvez Pérez, 1990). Appreciable differences in living standards, labour opportunities and the prospect of wealth increase, impel 
thousands of people every year to try to establish their residence in Spain. The border policies common to certain European countries (the Schengen agreements) constitute an additional incentive; thus in reaching a place in the European Union mobility becomes easier inside the whole community's territory. In this global context, there are numerous individual aspects that impel people from different countries to migrate to Spain. These immigration flows are common to a number of European countries (King, 1993).

Beside this basic economic cause, other reasons favour the continuous settlement of foreign residents in Spain. It is necessary to give these factors the importance they deserve. It must not be forgotten that there are also tens of thousands of foreign residents in Spain who, as pensioners, have chosen the country to live in, taking advantage of the favourable climate and the existing tourist and recreational facilities. In addition, with the help of tourism and the opening of the Spanish economy in general, thousands of people from EU countries have established their residence in the country in order to practise their diverse professions there. Analysing the origin of the migrants produces a number of interesting observations.

\section{The origin of foreign residents in Spain.}

An overall summary of migrant origins is provided in Table 4. For Europe and America intracontinental differentiations have been made.

Table 4. The origin of foreign residents in Spain.

\begin{tabular}{|c|c|c|c|c|c|c|c|c|c|c|}
\hline & \multicolumn{3}{|l|}{ Europe } & \multicolumn{4}{|l|}{ America } & \multirow{2}{*}{$\frac{\text { Africa }}{\text { Total }}$} & \multirow{2}{*}{$\frac{\text { Asia }}{\text { Total }}$} & Oceania \\
\hline & $\begin{array}{l}\text { European } \\
\text { Union }\end{array}$ & Remainder & Total & North & Centre & South & Total & & & Total \\
\hline 1975 & 92,917 & 9,785 & 102,702 & 12,041 & 23,740 & 48,142 & 48,142 & 3,232 & 9,393 & 440 \\
\hline 1980 & 106,738 & 11,634 & 118,372 & 12,363 & 8,569 & 25,769 & 46,701 & 4,067 & 11,419 & 518 \\
\hline 1990 & 231,162 & 38,860 & 270,022 & 21,186 & 10,621 & 48,751 & 80,558 & 25,854 & 29,116 & 1,103 \\
\hline 1995 & 235,858 & 19,844 & 255,702 & 19,992 & 23,993 & 64,947 & 108,932 & 95,718 & 38,352 & 733 \\
\hline 1997 & 260,599 & 28,485 & 289,084 & 18,261 & 34,300 & 74,398 & 126,959 & 142,816 & 49,110 & 888 \\
\hline
\end{tabular}

SOURCE: BASED ON DATA OF INE AND DIRECCIÓN GENERAL DE MIgRACIONES 
Table 5. Main source countries of immigration (residents as of December 31, 1997); absolute numbers and percentage of the total.

\begin{tabular}{lcc} 
Morocco & 111,109 & $18.2 \%$ \\
Great Britain & 68,271 & 11.1 \\
Germany & 49,890 & 8.1 \\
Portugal & 38,229 & 6.2 \\
France & 34,308 & 5.6 \\
Italy & 22,638 & 3.7 \\
Peru & 21,233 & 3.4 \\
Dominican Republic & 20,381 & 3.3 \\
Argentina & 17,188 & 2.8 \\
China & 15,754 & 2.5 \\
& & \\
\hline & & \\
Total of above & 399,001 & 65.43
\end{tabular}

SOURCE: BASED ON DATA OF THE INE AND DIRECCIÓN GENERAL DE MIgRACIONES

Some of the more outstanding points are as follows:

- The most important community of all, according to the most recent data, is made up of Europeans. They represent almost half of the total, but their level of importance is decreasing through time. In 1975 they represented 62.13\%. Over the years, their absolute number has grown substantially, but immigrants from other origins increased at a faster pace. In turn, there is a significant difference between people from the European Union and from the rest of the European countries. At present, the latter represent barely $11 \%$ of the total number of Europeans but the most recent data point to an appreciable tendency for change, with a rapid increase in the number of non-EU residents.

- It is not surprising that such immigrants are abundant in Spain. The proximity of some countries favours such moves. European economic integration equally facilitates movement, with more and more frequent exchanges inside the European Union. The entrance of Spain into the European Union (1986) was thus an important factor. The fall of the Berlin Wall and the disintegration of the regimes of the Eastern European countries also enhanced the speed and intensity of migratory flows (Castles \& Miller, 1995). In addition to labour motivations, we should also add that Spain is, for many people, a chosen place for retirement. In the coastal areas, as will be seen later on, the volumes attained are considerable.

- Immigrants of African origin now account for the next largest number. In 1997 they represented a little more than $23 \%$ of the total, whereas in 1975 they only accounted for 1.95\%. This spectacular rise is eloquent in itself: they have grown from only 3,232 in 1975 to 142,816 in 1997. The actual figures (including illegal residents) are certainly much higher. The proximity of the African continent to Spain is important, with the Strait of Gibraltar separating the Peninsula from Africa by only $14 \mathrm{~km}$ at its narrowest part. The situation is similar between the Canaries and the Moroccan coast. And if one considers the tremendous economic differences between Spain and the European Union and the immense majority of the African countries, one can understand the desire of many of their inhabitants to move toward the North.

Among the immigrants from Africa it is necessary to distinguish, in the Spanish case, on the one hand people from the Maghreb, mostly Moroccans, and on the other those who come from Sub-Saharan Africa. The former are the most numerous group (Gozálvez Pérez, 1993) 
although those from central and southern Africa are growing. Morocco stands out as the primary source country for immigrants to Spain.

- The jobs engaged in by the African immigrants generally require people with few skills, as is usually the case in migratory flows of a similar nature. Thus, a high percentage of the men engage in temporary work in agriculture where it is said that many of these immigrants are replacing the «jornaleros» or «braceros». Likewise, other occupations that employ many workers are in construction or the unspecialised jobs of the service sector, hotel services, domestic service and help in the home (especially in the case of women).

- There is also an appreciable number of immigrants from the American continent although their percentage has been diminishing while their total volume increased. They represented almost 30\% in 1975 but only a little more than $20 \%$ today. Although they are counted overall as Americans, the countries of the Ibero-American area are those that contribute the larger number of immigrants to Spain; in 1997 they represented $85.6 \%$ of the total from that continent. Linguistic and cultural affinities constitute a key factor that explains this, in addition to the tremendous economic difference between the north and the south of America.

- The structure of this group of American immigrants is rathermore complex and diverse than that of the Africans. On the one hand there are numerous people with a high skill level who, for various reasons, prefer to develop their profession in Spain. There are also many people whose moderate levels of skills, together with their knowledge of the Spanish language, allow them to quickly acquire jobs in accordance with their specialisations. But many others, because of their lack of skills, are involved in manual labour in the most diverse occupations, responding to labour demand.

- The Asians, lastly, only represent a very small number. Nevertheless, their tendency has been to become established, as the total of immigrants grew in Spain. This is confirmed when comparing the percentage values. So whilst in 1975 they only represented $5.68 \%$ of the total, in 1997 their contribution had increased to 8.06\%. Their origin is quite dispersed, because almost all the Asian countries are represented, although Chinese and Filipinos are most numerous. Because of this diversity few generalisations can be made about this community of immigrants.

More detailed research and smaller scales of analysis add nuances to the above. It should be taken into account that in dealing with non-organised immigration, family ties, relationships, and friendships generally have a considerable influence, at least in the beginning. "Chains» of connections are generated, where some help others in such a way that the natives of the same country or region end up residing together, or close to each other, in the new country. Something similar usually happens with regard to employment. This is not to postulate or to defend some deterministic position, but only to observe the reality and to look for the diverse causes and consequences that lie behind it.

\section{The uneven spatial distribution of immigrants in Spain}

The spatial distribution of the immigrants is very irregular and is not the result of chance. On the contrary, it is the consequence of the causes that have decided the destinations of the migratory flows. The data are provided in Table 6 and Figures 1 and 2 further illustrate this uneven territorial distribution. The most important issues to arise are as follows: 
Table 6. Uneven spatial distribution of foreign residents.

Total $\%$ of

total population

\begin{tabular}{lcc}
\hline & 109,129 & 1.50 \\
Andalusia & 15,449 & 1.30 \\
Aragon & 9,522 & 0.87 \\
Asturias & 38,959 & 5.12 \\
Balearic & 68,347 & 4.25 \\
Canaries & 4,546 & 0.86 \\
Cantabria & 12,739 & 0.74 \\
Castile-La Mancha & 22,908 & 0.91 \\
Castile-León & 183,736 & 3.01 \\
Catalonia & 80,594 & 2.01 \\
Valencian Community & 9,784 & 0.91 \\
Extremadura & 22,523 & 0.82 \\
Galicia & 158,885 & 3.16 \\
Madrid & 16,319 & 1.48 \\
Murcia & 8,131 & 1.56 \\
Navarra & 4,768 & 1.79 \\
Rioja, La & 18,622 & 0.88 \\
Basque country & 6,477 & 7.70 \\
Ceuta and Melilla & 9,891 & - \\
(interprovincial) & 801,329 & 2.00 \\
Spain &
\end{tabular}

SOURCE: BASED ON DATA OF THE INE AND DIRECCIÓN GENERAL DE MIgRACIONES

- As already indicated, the numbers of legal residents registered in Spain in 1999 had increased to 801,329 . This represented $2 \%$ of the total population of the country, a small proportion in comparison with other European countries. Except for the extreme case of Luxembourg, elsewhere the proportions are frequently between 5 and $10 \%$ of the total.

- Because of the variable size of the internal Autonomous Communities of Spain (both in terms of population and area) it is necessary to consider both the absolute numbers of foreigners and their contribution to the total population.

- The regions that surpass the national average are the Balearic and Canary Islands, Madrid, Catalonia and, of course, Ceuta and Melilla. It is appropriate to add some comments on these regions:

- The Spanish cities located in the North of Africa, Ceuta and Melilla, surrounded by Moroccan territory and having land borders with it in addition to easy marine access, make them significant and easily accessible places for immigration. At the beginning of the nineties, in order to prevent these borders from becoming a vulnerability for the Europe of Schengen, sophisticated protection systems were established, with barriers, sensors and so on, and police surveillance was intensified. Despite this there is a constant arrival of immigrants and the pressure exerted by those who want to enter is enormous. This periodically generates conflicts and explains the swollen percentage of foreigners.

- The two archipelagos, the Balearics and the Canaries, contain high proportions of foreigners for reasons which are similar, although with nuances of differentiation. Both sets of islands have been, for many years, top tourist centres, and a favourite destination for Europeans. Thanks to the pleasantness of their climate and their tourist-residential specialisation, they have become places of permanent residence for many foreigners. Very sizeable groups of Germans, English, Swedes, Danes and so on are found everywhere. In 
addition to those who are retired and choose the islands as an idyllic place of destination, there are also those who engage in work, often related with tourism. Although in the Balearics this typology of retired foreigners' residence is stronger, in the Canaries, with their proximity to Africa (a little more than $100 \mathrm{~km}$ at the closest point), there is a continuous and abundant arrival of illegal immigrants eager to enter Spain and the borders of the European Union. Although many are detected and expelled, there are not a few who escape those controls.

- The two other regions that also account for proportions higher than the mean are Madrid and Catalonia. They are similar in value to each other and slightly more than a percentage point above the Spanish average. This is due to the fact that these are the centres of the two main Spanish metropolitan areas, and at the same time have a rich industrial base and service sector activities. All this favours the arrival of numerous immigrants in search of jobs.

- Several other regions have foreigner proportions that are close to or slightly above the Spanish average. This group includes the Valencian Community, La Rioja, Navarra, Andalusia, and Murcia. Almost all are located in the area of the Mediterranean Levant. Although there are notable differences between them, in economic aspects and in productive structure, almost all have strong agricultural sectors and an abundance of intensive cultivation that requires plentiful manpower that is often supplied by immigration. The presence of rich tourist services also acts as an attraction for numerous immigrants. In the case of Navarra and La Rioja, although their socio-economic and productive features are somewhat different from those indicated above, their regional economies are growing at a good rate and their unemployment rates are almost nonexistent. Their demographic weakness also explains the remarkable arrival of immigrants.

- Immigration is more limited in the rest of the Spanish regions. This particularly applies in extensive areas of the interior centre, north and northwest. Their economic structures are, to a considerable extent, the reverse of those referred to in the aforementioned regions. Without a doubt this explains the limited presence of foreign residents.

- It is necessary to conclude this section by pointing out that the tendency observed during recent years confirms the generalisation that it is primarily labour objectives that have brought immigrants to Spain as a whole. However, their distribution is then governed by local factors of favourability.

\section{Recent and sudden changes in immigration. Beyond legality} extent of illegality causes certain anxieties, since numerous groups of immigrants are deprived of their rights and subjected to blackmail and extortion. This benefits the unscrupulous who take advantage of such situations. There has been an identification of «mafias» that make immigration the central objective of their business, often unknown to their own fellow countrymen. Let us briefly examine these issues.

29

From the beginning of the 1990s the authorities became aware of the dimension and continuity of the immigration flows, and soon initiated the first control measures. After the regularisation at the beginning of 1990-91 (Aragon Bombín \& Chozas Pedreros, 1993), they resorted in a timid fashion to annual quotas. In the first year the quota was fixed at 5,197. The next year, 1994, it increased to 25,$604 ; 19,946$ permits were granted 
in 1995. In 1996, when a new regularisation process was carried out, no additional quota was established. In 1997 the quota increased to 24,585 , a figure similar to that of 1994. In 1998 that figure increased slightly to 28,095. One has the feeling that the central government's policies in these matters move timidly, pulled by circumstances. This creates a vicious circle: the authorities only authorise reduced annual quotas, knowing that the real number of immigrants who enter is greater. In doing so they create the situation of illegality for those who enter on the margins of the granted authorisations: this increases the division between legal and irregular/illegal immigrants. The result is the periodic creation of an extraordinary regularisation procedure, and then the cycle begins again.

30 As a result of existing legal and normative controls, both of Spain itself and of the whole European Union, and because of the constant and growing pressure of people willing to enter Spain, either to reside definitively there or to reach another European country, the number of illegal residents present on Spanish soil is always considerable. The latest regulation process is currently in operation. It began in the first months of 2000 and there was a period to submit applications. Irrespective of the nature of the conditions for regularisation, only those who expected a favourable result to their requests have submitted applications. By November 13, 2000 there had been a total of 244,394 applications, a much higher figure than expected. This means that if we add to the legal residents counted in 1999 the total of present foreigners who have manifested a desire to be legalised in Spain, it exceeds the figure of a million foreign residents. But that is not everything. It is known that there have been several tens of thousands more newcomers in Spain during the last months who, knowing that their regulation petition wouldn't receive a favourable response, have not even presented applications. It is impossible to know how many they are. But everything leads to the observation that the real number of foreigners present in Spain already amply exceeds the figure of a million referred to above. This gives us an idea of the real dimension attained by immigration in Spain.

31 Over the coming years it seems that the phenomenon will continue with similar tendencies, given the structural causes in existence. The following suggestions can be made:

- There will not be a modification of Spain's favourable geopolitical location as a place at the crossroads among continents, a natural path between Africa and Western Europe. The Iberian peninsula provides a natural bridge from the South as well as easy access from IberoAmerica. Spain will always be a first link or the final destination of emigration flows from the South to the North (SOPEMI, 1999).

- The very process of European integration indicates that controls will be reduced gradually among the member states, so that the desire of those wishing to enter the Union is to do so through those places that are wither closer in proximity to their places of origin, or are easier to access as a result of weaker controls. Once settled in the EU's territory, they move on to a place that is better adapted to their needs.

- As the gulf of economic structure, of social wellbeing and of opportunities grows between the EU and its neighbours, migratory flows toward the EU will grow stronger and more intense. Even if the borders are reinforced, it will be impossible to stop determined people from entering. Various restricting measures will be able to mitigate the flows but not put an end to them. 
- The presence of several million immigrants (possibly about 20 million) inside the European Union, of which Spain accounts for more than a million, will in the future facilitate the arrival of thousands of their countrymen willing to undertake migration.

In addition to these broad issues referring to the European Community, other causes particular to Spain exist.

- During the last half decade Spain has experienced a strong pulse of economic growth. The modernisation and structural transformation of all the productive sectors have been and continue to be spectacular. Years of diminished growth in this cycle, or of economic crisis, have not reduced the force of the dominant overall tendency (Serrano Martínez \& Calmés, 1998b). In the same way, social programmes have been substantially improved in terms of their coverage of individual. All this constitutes an appropriate setting necessitating abundant manpower to reduce the tensions caused by the excess of demand over labour supply.

- There appears to be a contradiction between the level of official unemployment registered in Spain and the appreciable number of immigrants. But although the 'official' unemployment figures in Spain are high, their tendency in recent years has been towards decline. At the present time, data from the National Institute of Statistics, which enumerates the numbers registered in unemployment centres, total more than a million people, about $10 \%$ of the active population. Further, the Survey of the Active Population almost doubles that figure. It is difficult to see how these figures can be reconciled with the several hundreds of thousands of foreigners who work in Spain.

- However it is necessary to add two more aspects. On the one hand, much of the work carried out by the immigrants concerns temporary positions, where 'temporary' is a constant circumstance: many of the agricultural jobs and work related to tourism, two strong sectors of the Spanish economy, are good examples of this. Indigenous Spanish workers are not always willing to accept such jobs, which are frequently hard and little remunerated. On the other hand, managers have discovered the ease with which the new residents are willing to take low skilled and low waged jobs, hence their willingness to hire the foreigners. It is employers and managers who most favour the admission of new immigrants. For their part, indigenous workers, with their basic needs covered by generous social policies, are reluctant to dedicate their effort to the many occupations carried out willingly by foreign immigrants. The result is that, up to the present, no notable tensions have arisen in this respect (cf. Aguilera Arilla et al., 1993).

- The lack of experience in immigration matters on the part of all the competent Spanish authorities has resulted in zigzag policies, which have lacked consistency and which in no way favour harmonious development in this area. There has even been some talk of the «anticipated effect» that is sometimes generated by abrupt changes in immigration policy.

\section{Clarifications on the structure and different typologies of foreign residents in Spain}

As indicated earlier, it is necessary to clearly distinguish the different features, the disparate significance and consequences of the varied groups of foreigners currently residing in Spain.

- Foreign pensioners residing in Spain. These constitute a significant number, amounting to several tens of thousands (Rodríguez Rodríguez, 2000), although a large part of them are not even enrolled as such and are thus excluded from official statistics. The majority are from 
neighbouring European countries and belong to middle and upper economic groups. Settled by preference in the coastal areas of the Mediterranean and the islands, their intention is to spend several years of their lives in these new residences, whilst they are still able to look after themselves. Such a phenomenon is common to all of southern Europe and to other warm areas of the planet (Hazelrigg \& Hardy, 1995). Their existence is related to the tourist and leisure policies of the country. They pose interesting questions with regard to their integration and other related aspects of their local residence. With regard to the future, it is probable that there will be an increase in their numbers (King, Warnes \& Williams, 1998).

- People from other countries of the European Union who are working in Spain. They constitute a substantial group, characterised by their heterogeneity, as much by their origin, as by the diverse occupations and tasks they carry out. As a result of EU legislation, they are not subject to control in their movements nor in the establishment of residence inside the territory of the Union. The tendency, if the European Union consolidates, is to consider them on a parity with the rest of the citizens of the country where they reside. It is not necessary therefore to consider them as subject to future immigration policy (Balao, 1994). For all the reasons indicated earlier, their numbers are likely to increase in the future. It is also believed, for various reasons, that areas of southern Europe present a certain attractiveness to such migratory flows (Arango, 1993).

- In this discussion, it is the workers from other non-EU countries who pose certain more complex questions for migration policies. As already pointed out, until only a decade ago, their number was insignificant; today they are an appreciable community with vigorous growth. There have been several hundreds of thousands of people arriving in Spain during recent years in search of work and a better life. They come from numerous countries and areas of the world. Most of them are men and are low skilled. For that reason they have to accept the types of specific jobs rejected by the indigenous population. The first to arrive in large numbers were groups of Ibero-Americans expelled by the dictatorships and attracted by the linguistic facility offered in Spain. This contributed to their social integration (Martínez Veiga, 1997). Only in two 5-year periods have they been surpassed in number by immigrants from the Maghreb (resulting from spatial proximity) and other communities of Sub-Saharan Africans, in addition to a smaller, but varied, group of Asians. Recently those coming from several Ibero-American countries have also been increasing as a result of their extensive and widespread economic crises.

In dealing with further details on foreign residents in Spain, the diversity of their origins has to be borne in mind, as well as the deficiencies of data sources, and the strong component of illegality in certain groups.

One element of interest concerns the gender balance. The most reliable statistics, in this respect, are derived from work permits granted annually. This is certainly not an absolute indicator, since many people do not request a permit because they are illegal or have already obtained a more stable situation after several years of residence. But the available data can be of some use.

The inequality between men and women is still marked although during the course of recent years there is evidence of a remarkable increase in women. Regarding occupations, the data in Table 7 are of interest. 
Table 7. Proportion of men and women, according to work permits granted.

\begin{tabular}{lcc} 
& 1992 & 1997 \\
\hline Men & $71.34 \%$ & $63.22 \%$ \\
Women & $28.16 \%$ & $36.78 \%$
\end{tabular}

SOURCE: BASED ON DATA OF THE MINISTRY OF LABOUR AND SOCIAL AFFAIRS

37 Table 8 shows that agriculture and services (in low-skilled positions) are the sectors with the greatest demands for foreign residents' labour; this is not related to the overall structure of Spain's active population (Pedreño Canovas, 1999).

Table 8. Labour activity carried out by foreign residents, according to the work permits granted.

\begin{tabular}{lcc} 
& 1992 & 1997 \\
\hline Agriculture & $13.17 \%$ & $23.52 \%$ \\
Industry & $8.90 \%$ & $6.63 \%$ \\
Construction & $14.21 \%$ & $8.24 \%$ \\
Services & $63.72 \%$ & $61.61 \%$
\end{tabular}

SOURCE: BASED ON DATA OF THE MINISTRY OF LABOUR AND SOCIAL AFFAIRS

Another central question is the occurrence of legality/illegality in Spain as we have seen previously. But this problem remains unsolved (Cebrián \& Bodega, 2000). The presence of hundreds of thousands of immigrants poses numerous questions for the future, such as: is it permanent or temporary immigration? Again, the answer is unknown. At the moment, as the pattern of immigration has developed, the features are typical of early migratory movements. For the most part, it consists of single men; the presence of complete family units as well as that of children is as yet very scarce. Given that total figures for family residents for the whole country are not available, it would be of interest to know the data that record the residence permits for family regroupings granted last year, included for the first time in the Anuario de Migraciones. A total of 23,972 were requested, of which 15,061 were granted and 8,911 refused. This serves as an illustration of the clear tendency towards stability that immigration now seems to show in Spain.

Likewise, the number of children and young people, the children of immigrants, tends to increase. This constitutes an indicator of the permanency of the immigration phenomenon, and at the same time aids the better integration of the immigrant population.

40 Although the figures in Table 9 are not very high, and represent only a short timeseries of data, they confirm the growing presence of foreign children enrolled in school. 
Table 9. Foreign residents' children in Spain: Enrolled non-university students.

1994-95

1995-96

1996-97
53,213

53,262

62,708

SOURCE: BASED ON DATA OF THE MINISTRY OF LABOUR AND SOCIAL AFFAIRS

41

The other hand, the increase in the naturalisa
The summarised data are provided in Table 10.

Table 10. Evolution of the naturalisation of foreigners in Spain.

\begin{tabular}{lr}
$1975-80$ & 12,052 \\
$1981-85$ & 25,396 \\
$1986-90$ & 39,046 \\
$1991-96$ & 36,668 \\
1997 & 10,311 \\
\hline & \\
\hline Total & 123,473
\end{tabular}

SOURCE: BASED ON DATA OF THE MINISTRY OF LABOUR AND SOCIAL AFFAIRS

The continuous presence of foreign residents in Spain creates a situation in which many of them, after a period and once they have achieved a stable personal situation, desire to attain Spanish nationality so as to continue to live in Spain indefinitely. The figure is not inconsequential, although quite small in comparison with the total volume of foreign residents. But the obstacles and difficulties in attaining nationality are considerable, and this constrains their number.

\section{Reflections on the design of an immigration policy}

The number of elements involved and the multitude of causes and consequences that they involve make migration a complicated matter. Entrenched polemic positions also exist. It must be argued that migration questions should be considered with realism and attention because amongst the interested parties, the immigrants are the weakest, and they are in an inferior position compared to the receiving country's nationals. Immigrants should be seen as people with certain inalienable rights who should always be protected. Simplistic positions are dangerous because, among other things, those most harmed by such arguments in the long run can be the immigrants themselves.

At present a clear contradiction exists. Everything with respect to economic and productive activities develops within clearly liberal positions with few limits and obstacles between states; on behalf of liberalism the disappearance or reduction of the existing barriers is promoted. However, this does not involve the free circulation of people. Few defend this position (Hammar, 1990). Free circulation of people would most probably bring enormous chaos, as the richest and most developed countries would be 
invaded by poorer multitudes (Carens, 1987). No sensible person would propose such a radical and brusque change. But this brings another important question: why does each country have the right to fix immigration policy in a discretionary and free way? The easy answer refers to issues of a country's own sovereignty. But the issue of whether national policies should ignore the realities of neighbouring countries remains without an answer.

All countries, through their democratically-elected authorities, can establish their own migratory policies, but they should do so with supreme care and always considering the medium term and not merely the questions of the moment. It has been said that fear, the fear of others, is and has always been a component of human behaviour. But this fear had more justification when the other was a stranger of whom little was known. Today the issues are different: no human community is unknown. We are in a global village, where those who want to can know much about everyone. But maybe these new structures paradoxically spur the desire of human groups to take refuge in the most intimate elements of cohesion - inheritance from the tribe. Some see the present burst of nationalism as a reaction to relentless globalisation.

One of the fundamental justifications of the state is its capacity to defend the equality of all the citizens and to protect minorities' rights. But in these desirable processes there is always a major dilemma: the dialectic between homogeneity-equality and diversity. Without a doubt tolerance is the way that assures coexistence. But to what extent can a state collective exist alone, different from others, with a notable degree of diversity at its heart? In other words, what degree of homogeneity is necessary for a state to continue existing as an independent entity? These are questions that arise from the consideration of the possible scope and implications of immigration policies.

From Spain's specific perspective, it seems that a basic issue is that the country should above all try to attain a 'migration policy' that achieves the maximum consensus of the political forces and has corresponding social support. The policy needs to be such that there is a general recognition that alternances of the party in power will not involve significant changes to the policy or its implementation. This doesn't mean that unanimity should be sought. That is impossible in a democracy. But short-sighted attitudes redound to the detriment of in damage to the country. This is what happened with the prevailing 'Aliens Law', which was approved with a small majority and after appreciable disagreements among the main political forces. The change in the political balance at the beginning of 2000 resulted in proposals for changes in this law such that in its original form it may only be in effect for a few months.

It is important to determine whether there are certain common interests of the state in the question of foreign residents. Given the complexity of the factors involved and the heterogeneity of these residents, this is not a simple question; many nuances are involved. It is necessary to take into account that there are now something over 800,000 legal residents, and if we add those who are pending in the admission process it easily surpasses a million persons, besides those who have not asked to be included. The grand total may be around 1.3/1.4 foreign million people who clearly reside, work or, as pensioners, simply live their retirement in Spain. The current behaviour of the government seems logical, given the present extraordinary controls, in attempting to understand the existing situation as well as it can in order to find a starting point for action. However, this takes time and the arrival of immigrants is continuous. On the margins of what is being done and what the law says, asylum applications are the result 
of the structural causes seen in the preceding pages. In great part this is because there still exists a certain margin of internal manoeuvre, and the existing situation favours the arrival of people. But because of the cautious actions of the public authorities, reality is greater than the capacity of the legal and official to deal with it. A stable longterm migratory policy is needed, in order to avoid bigger problems and to serve as a legal guarantee.

Because the established quotas have been reduced, the majority of newly-arriving immigrants now make their way quasi-legally, or illegally, through clandestine methods. Perhaps it would be a more realistic and courageous procedure to enlarge the quotas, if the job supply is really large enough, relying on the formulation of temporary contracts. This could bring proceedings into accordance with reality. Instead it could be argued that there seems to be a certain fear of establishing a system of more realistic, but closed and less flexible, quotas. It is argued that it would constitute an arbitrary, discriminatory, and selective system. But perhaps it is worse to continue as now, with symbolic quotas and most of the immigrants entering on the margins of the law.

Returning to the basic idea of looking for the common interest of the nation, it is worth considering which immigration model is necessary or desired. To design it, it is necessary to start from some basic aspects referring both to the nature and structure of the community of existing immigrants, as well as to other aspects of Spanish society. Very briefly, some of the related questions are as follows:

- A question that seems reasonable to pose is whether Spain's needs for working immigrants are temporary or definitive? And, as a result, what is the necessary number? Such a position can be rejected as selfish, since it is formulated from the viewpoint of the receiving country, but it is difficult and may not be very realistic to take another position - to consider it from the interests of the people who want to come. Indeed it is only from realism that one can attain a certain functionality, starting from the basic assumption of considering immigration as something enriching that contributes to the development of the receiving society. Many new countries provide good examples. New foreign residents are no parasites, but people willing to work, to produce, to pay their taxes and collaborate in the creation of a so-called 'state of well-being' in which all participate.

- Whatever receiving countries do, we should recognise that immigration pressure from the Third World will undoubtedly continue. The future result must be international cooperation seeking a better balance of wealth and less concentrated global development, extended to the greatest possible number of countries. However, this is very easy to enunciate but very difficult to put into practice, due to the predominant structures of the planet.

- If within Spain it is decided that the country needs a certain number of immigrants, or that the Spanish society can absorb a certain number, it will be necessary to make an effort to adapt the reception mechanisms in such a way that the new residents feel comfortable and become as integrated as possible. This should not only happen for altruistic reasons, but because of simple justice, thinking of the rights of the people who arrive. As it is certainly not easy accurately to determine existing needs ahead of time, any responsible person should advise a certain caution when gauging the numbers to be involved. But it should equally be held that, given the nature of those involved, they cannot under any circumstances be treated as being on the margins of human rights. The result is that maintaining any simplistic exclusion, in the medium or the long term, is suicidal for the 
receiving society. Promoting or favouring a totally open door can only lead to a fragmentation of society.

- Reference has frequently been made to current Spanish demographic weakness. The fertility rate is among the lowest in the world. At the same time, the ageing of the population increases, and inter-generational replacement is not guaranteed. Demographic projections forecast a decrease in Spain's total population in the medium term, leading some to defend the more generous opening of the doors to immigration, as a help to bolster the Spanish population's weak evolution. This could be a reason, but it doesn't seem to be a sufficient reason to do so.

- It is not easy for states to combine logical protection of the domestic labour market with a calculated opening of the borders to immigration. But what favours nobody is the maintenance of not very coherent immigration policies that are short sighted and of a changeable and restrictive nature. The challenges for Spain and all developed countries are considerable in these matters. Imagination and generosity are needed, coloured with the realism that is always necessary so as not to make mistakes in proposals and actions. Clear and stable legislation benefits everyone.

51 For these reasons the changes observed in the patterns of immigration in Spain are significant in terms of both the speed of development and the extent of the effects.

\section{BIBLIOGRAPHY}

AGUILERA ARILLA M.J., GONZÁLEZ YANCI M.P., RODRÍGUEZ RODRIÍGUEZ V. (1993), «Actitudes de la población espa-ñola ante los inmigrantes extranjeros». Estudios Geográficos, 210, pp. 145-54.

ARAGÓN BOMBÍN R., CHOZAS PEDREROS J. (1993), La regulación de inmigrantes durante 1991-92, Ministerio de Trabajo y Seguridad Social, Madrid.

ARANGO J. (1993), «El Sur en el sistema migratorio europeo. Evolución reciente y perspectivas», Política y Sociedad, 12, Madrid, pp. 34-49.

BALAO P. (1994), Ciudadanos europeos residentes en España. Aproximación a su situación actual, Ministerio de Asuntos Sociales, Cáritas, Madrid, 3 vols.

CARENS J.H. (1987), «Aliens and Citizens: The Case for Open Borders», Review of Politics, IL, pp. 251-73.

CASTLES S., MILLER M. (1995), The Age of Migration, Macmillan Press, Londres

CEBRIÁN J.A., BODEGA M.I. (2000), «Solidaridad y ciudadanía: los inmigrantes en la España de hoy», Vivir la diversidad, Aportación Española al XXIX Congreso Geográfico Internacional, Seul, Asociación de Geógrafos Españoles, Real Sociedad Geográfica, Madrid, pp. 10-24.

GARCÍA FERNÁNDEZ J. (1965), La emigración exterior española, Ed. Ariel, Barcelona, 262 pp.

GOZALVEZ PÉREZ V. (1990), «El reciente incremento de la población extranjera y su incidencia laboral», Investigaciones geográficas, 8, pp. 7-36. 
GOZÁLVEZ PÉREZ V. (1993), «La migracion magrebí en Europa. El caso de España», Polígonos, 3, pp. 59-87.

GOZÁLVEZ PÉREZ V. (1996), «L'immigration étrangère en Espagne (1985-1994)», Revue Européenne des Migrations Internationales, 12, 1, pp. 11-38.

HAMMAR T. (1990), Democracy and Nation State: Aliens, Denizens and Citizens in a World of International Migration, Avebury, Londres.

HAZELRIGG L. E., HARDY M.A. (1995), «Older adult migration to the Sumbelt. Assessing income and related Characteristics of recent migrants», Research on Ageing, 17, 2, pp. 209-234.

HERMET G. (1969), Los españoles en Francia: inmigración y cultura, Guadiana de Publicaciones, Madrid, $294 \mathrm{pp}$.

IZQUIERDO A. (1995), La inmigración en España, 1980-90, Ministerio de Trabajo y Seguridad Social, Madrid.

KING R. (1993), Mass Migration in Europe. The Legacy and the Future, Belhaven Press, Londres.

KING R. WARNES A., WILLIAMS A.M. (1998), «International retirement migration in Europe», International Journal of population Geography, 4, 2, pp. 91-111.

LÓPEZ DE LERA D. (1995), «La inmigración en España a fines del siglo XX. Los que vienen a trabajar y los que vienen a descansar», Revista Española de Invesigaciones Sociológicas, 71-72, pp. 225-45.

LÓPEZ TRIGAL L. (2000), «La diversidad e integración de la inmigración extranjera en España», Vivir la diversidad. Aportación Española al XXIX Congreso Geográfico Internacional, Seul, Asociación de Geógrafos Españoles, Real Sociedad Geográfica, Madrid, pp. 157-74.

MARTÍNEZ VEIGA U. (1997), La integración social de los inmigrantes en España, Ed. Trotta, Madrid, 299 pp..

MUÑOZ PÉREZ F., IZQUIERDO ESCRIBANO A. (1989), «L'Espagne, Pays d'immigration», Population, no 2, pp. 257-89.

PALAZÓN FERRANDO S. (1999), «La emmigración exterior española en el contexto de la transición demográfica (1880-1975)», en GOZÁLVEZ PÉREZ V., Europa: una demografía en transición, Universidad de Alicante, A. Benissa, pp. 55-76.

PARRA F. (1981), La emigración española en Francia, 1962-1977, Instituto de Estudios Económicos, Madrid.

PEDREÑO CÁNOVAS, A. (1999), «Construyendo la Huerta de Europa: trabajadores sin ciudadanía y nómadas permanentes en la agricultura murciana», Migraciones, nํ5, pp. 87-120.

RODRÍGUEZ RODRÍGUEZ V. (2000), «Vivir en España: Jubilados europeos en las costas españolas», Vivir la diversidad. Aportación Española al XXIX Congreso Geográfico Internacional, Seul, Asociación de Geógrafos Españoles, Real Sociedad Geográfica, Madrid, pp. 193-216.

SÁNCHEZ ALONSO B. (1995), Las causas de la emigración española (1880-1930), Alianza Editorial, Madrid.

SEMPERE SOUVANNAVONG J.D. (2000), «La disminución de inmigrantes españo-les en Francia», Estudios Geográficos, 239, LXI, pp. 353-376.

SERRANO MARTÍNEZ J.Ma . (1995), «España: ¿Hacia un cambio de sentido de los movimientos migratorios? Análisis particular de la inmigración magrebí (1975-1994)», Awraq, XVI, Instituto de Cooperación con el Mundo Árabe, Madrid, pp.185-216. 
SERRANO MARTÍNEZ J.Mํa (1997), Procesos de desarrollo y cambio territorial en España durante los años postreros del Siglo XX, Universidad de Murcia, 450 pp.

SERRANO MARTÍNEZ J.Mª. (1998a), «The Spanish cycle of migration to Western Europe, 1960-90», Bulletin de la Societé Belge d'Etudes Géographiques, 2, pp.163-180.

SERRANO MARTÍNEZ J.Ma., CALMÉS R. (1998b), L’Espagne. Du sous-développement au développement, L'Harmattan, Paris, 302 pp.

SOPEMI (1999), Trends in International Migration, Paris, OCDE.

VILAR J.B., VILAR Ma J. (1999a), La emigración española a Europa en el siglo XX, Ed. Arco Libros, S.L., Madrid, 93 pp.

VILAR J.B., VILAR Mํ.J. (1999b), La emigración española al Norte de África (1830-1999), Ed. Arco Libros, S.L., Madrid. 79 pp.

VILAR, J.B. (2000), «Las emigraciones españolas a Europa en el siglo XX: algunas cuestiones a debatir», Migraciones \& Exilios, 1, pp. 131-159.

WILLIAMS A.M. et al. (1997), «A place in the sun: international retirement migration from Northern to Southern Europe», European Urban and Regional Studies, 4, 2, pp. 115-134.

\section{ABSTRACTS}

Spain is a country that, within a few years, has experienced a drastic change in its migratory behaviour. It has passed from being an emigration country to one of immigration. But, in turn, the numbers of foreign residents in Spain do not fit a single immigration model. Several such models apply, relating to migrant origins and objectives. All this happens within the framework of a European panorama involving a substantial arrival of immigrants in countries which are economically mature but also dynamic in economic growth terms. These considerable immigration flows, of continuous growth, are occurring in a world context where the speed and ease of movement is increasing. For the future, it seems opportune to design sensible and reasonable immigration policies with a view to their likely relevance over the medium term.

L'Espagne est un pays dont le comportement migratoire a connu un bouleversement complet en l'espace de quelques années. Jadis pays d'émigration, l'Espagne est à présent devenue une terre d'immigration. Mais la totalité des résidents étrangers en Espagne n'appartient pas à un unique modèle migratoire. Il convient en effet de distinguer, en fonction de l'origine et des aspirations des immigrants, différents modèles, qui tous s'inscrivent dans un panorama européen témoin d'une forte arrivée d'immigrés dans des pays économiquement matures et dynamiques en termes de croissance économique. Ces importants flux d'immigration, en augmentation constante, se situent dans un contexte mondial où la rapidité et la facilité des déplacements ne cessent de croître. Face à l'avenir, il semble opportun de concevoir des modèles d'immigration sensés et raisonnables, susceptibles de se maintenir à moyen terme.

\section{INDEX}

Mots-clés: migrations internationales, modèles migratoires, politique d'immigration, Espagne

Keywords: international migratory moves, migratory models, immigration policy, Spain 


\section{AUTHOR}

\section{JOSÉ Ma . SERRANO MARTÍNEZ}

Chair Professor of Regional Geographical Analysis, Department of Geography, Campus La Merced, 30001 Murcia, Spain, jmserran@fcu.um.es 